\title{
Structure and properties of the graphene and diamond-copper composites fabricated by the high pressure-high temperature method
}

\author{
Struktura i właściwości kompozytów \\ miedź-grafen oraz miedź-diament, wytworzonych za pomocą \\ metody wysokiego ciśnienia i wysokiej temperatury
}

\author{
KATARZYNA JANIK \\ TOMASZ CZEPPE \\ LUCYNA JAWORSKA \\ PAWEŁ FIGIEL \\ LIDIA LITYŃSKA-DOBRZYŃSKA \\ PIOTR OZGA *
}

\begin{abstract}
The paper presents results of microstructural examination as well as chosen mechanical properties of graphene and diamond rich-copper composites fabricated by the high pressure-high temperature method. The composites were tested for density and elastic properties of the sintered compacts by use ultrasonic flaw detector. KEYWORDS: composites, Cu-graphene, Cu-diamond, HPHT sintering
\end{abstract}

Przedstawiono wyniki badań mikrostruktury i wybranych właściwości kompozytów grafen-miedź oraz diament syntetyczny-miedź, o wysokiej zawartości grafenu oraz diamentu, wytworzonych za pomoca metody wysokiego ciśnienia-wysokiej temperatury. Wyznaczono gęstości pozorne spieków oraz własności sprężyste metodą defektoskopii ultradźwiękowej.

SŁOWA KLUCZOWE: kompozyty, Cu-grafen, Cu-diament, spiekanie HPHT

Graphene is unique material with 2D, honeycomb structure. Since 2010 Nobel prize in physics, graphene gained much attention in science. Because of his unique mechani$\mathrm{cal}$, thermal and electronic properties graphene has the potential to be used in many applications in functional materials [1]. The synthetic diamond particles may play a role of strengthening element in the metal-matrix composites [5]. The structure and properties of graphene-rich and diamondrich -copper composites have been studied. The reason for the investigations was to examine structure and elastic properties of composites synthesised from powders by the high pressure, high temperature (HPHT) procedure, based on the Bridgman method. Due to high pressure and high temperature, sintering takes place much faster than in case of free sintering method. Reduction of the processing time contributes to the limitation of grain growth, which is important in powders sintering. In Bridgman apparatus the compression, which is quasi- hydrostatic, is a result of the plastic deformation of a ,,gasket" material. Almost all pro-ducts of HPHT reveal $100 \%$ of densification and isotropy of properties.

\footnotetext{
* Mgr inż. Katarzyna Janik (k.janik@imim.pl), dr hab. Tomasz Czeppe, prof. PAN (t.czeppe@imim.pl) - Instytut Metalurgii i Inżynierii Materiałowej PAN; prof. dr hab. inż. Lucyna Jaworska (lucyna.jaworska@ios.krakow.pl), dr inż. Paweł Figiel (pawel.figiel@ios.krakow.pl) - Instytut Zaawansowanych Technologii Wytwarzania; dr hab. Lidia Lityńska Dobrzyńska, prof. PAN (I.litynska@imim.pl), dr hab. Piotr Ozga, prof. PAN (nmozga@imimpan.krakow.pl) - Instytut Metalurgii i Inżynierii Materiałowej PAN
}

\author{
DOI: 10.17814/mechanik.2016.5-6.57 \\ Międzynarodowa Konferencja IMT 2016
}

\section{Experimental procedure}

The composites were made by use of the HPHT method. The sintering process was conducted under high pressure and at high temperature, in a short period of time. The powders were preliminary carefully mixed with use of the ultrasonic vibrations [4]. For this the powders were immersed in isopropyl alcohol suspended. The mixtures were prepared from $20 \%$ vol. of copper (LT 16, granulation under $63 \mu \mathrm{m}$ ) and $80 \%$ vol. of graphene or diamond. The grades of graphene and diamonds powders used are given in Tab. I. The parameters of the HPHT processes, the same for all the samples, are given in Tab. II.

TABLE I. Grades of graphene and diamond powders

\begin{tabular}{|l|l|}
\hline \multicolumn{1}{|c|}{ Sample } & \multicolumn{1}{c|}{ Grades } \\
\hline $\mathrm{Cu}_{-} \mathrm{C}_{\mathrm{Gn}}(4)$ & $\begin{array}{l}\text { graphene nanoplatelets (GNPs), grade 4, } 4 \mathrm{~nm} \\
(<4 \text { layers }) />700 \mathrm{~m}^{2} / \mathrm{g}, \mathrm{HDPlas}\end{array}$ \\
\hline $\mathrm{Cu}-\mathrm{C}_{\mathrm{Gn}}(10-20)$ & $\begin{array}{l}\text { grade } 10 \div 20 \mathrm{~nm} \times 14 \mu \mathrm{m} / 21 \mathrm{~m}^{2} / \mathrm{g}, \mathrm{N} 006-\mathrm{P} \\
\text { Polar Graphene Powder }\end{array}$ \\
\hline $\mathrm{Cu}-\mathrm{C}_{\mathrm{D}}(3-6)$ & $\begin{array}{l}\text { grade } 3 \div 6 \mu \mathrm{m}, \text { Element6, Micron+MDA, M36, } \\
\text { diamond powder }\end{array}$ \\
\hline $\mathrm{Cu}-\mathrm{C}_{D}(0-1)$ & $\begin{array}{l}\text { grade } 0 \div 1 \mu \mathrm{m}, \text { Element6, Micron+MDA, M01, } \\
\text { diamond powder }\end{array}$ \\
\hline
\end{tabular}

TABLE II. HPHT parameters

\begin{tabular}{|c|c|c|c|c|c|}
\hline $\begin{array}{c}\text { Pressure } \\
\mathrm{GPa}\end{array}$ & $\begin{array}{c}\text { Power } \\
\mathrm{kW}\end{array}$ & $\begin{array}{c}\text { Temp. } \\
{ }^{\circ} \mathrm{C}\end{array}$ & $\begin{array}{c}\text { Time of } \\
\text { heating } \\
\mathrm{s}\end{array}$ & $\begin{array}{c}\text { Time of } \\
\text { sintering } \\
\mathrm{s}\end{array}$ & $\begin{array}{c}\text { Time of } \\
\text { cooling } \\
\mathrm{s}\end{array}$ \\
\hline 7.7 & 3.5 & 1050 & 90 & 60 & 5 \\
\hline
\end{tabular}

As a result of sintering the compacted samples were obtained. The samples of following diameters were produced:

- $\mathrm{Cu}-\mathrm{C}_{\mathrm{GN}}(4)-15.25 \times 4.7 \mathrm{~mm}$,

- $\mathrm{Cu}-\mathrm{CGN}_{\mathrm{GN}}(10-20)-15.41 \times 4.59 \mathrm{~mm}$

- Cu$_{-} \mathrm{C}_{\mathrm{D}}(0-1 \mu \mathrm{m})-13.79 \times 4.04 \mathrm{~mm}$

- $\mathrm{Cu}-\mathrm{C}_{\mathrm{D}}(3-6 \mu \mathrm{m})-13.78 \times 3,95 \mathrm{~mm}$

The sintered compacts are shown in Fig. 1.

\section{Results and discussion}

The microstructure of the samples was investigated with light and transmission electron microscopes (TEM). The light microscopy microstructure are shown in Fig. 2.

The polished surfaces of samples after cutting the edge were observed with magnifications 10, 20, 50x. In Fig. 2 the 
aggregations of copper may be noticed. It is a result of mixing of powders before sintering process followed by draying.
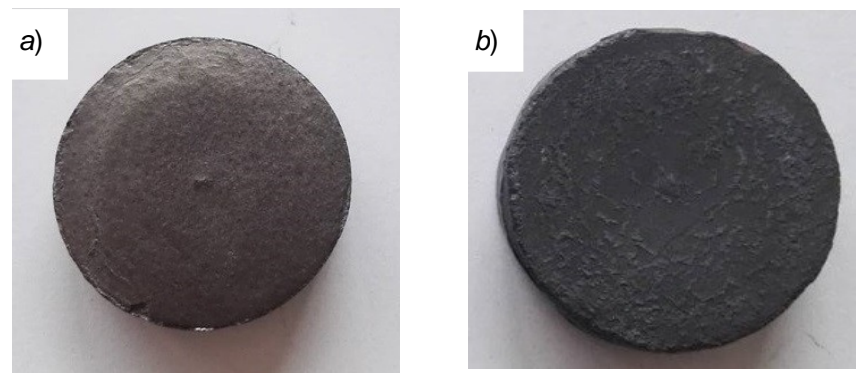

Fig. 1. Sintered compacts: directly after sintering: a) $\mathrm{Cu}_{\mathrm{GN}}(4)$, b) $\mathrm{Cu}-\mathrm{C}_{\mathrm{D}}(3-6)$

During evaporation of isopropyl alcohol the formation of clusters proceeded. To reduce the problem, dry and mixed powders were homogenised with agate mortar. Unfortunately, aggregation of the powders was unavoidable [2].
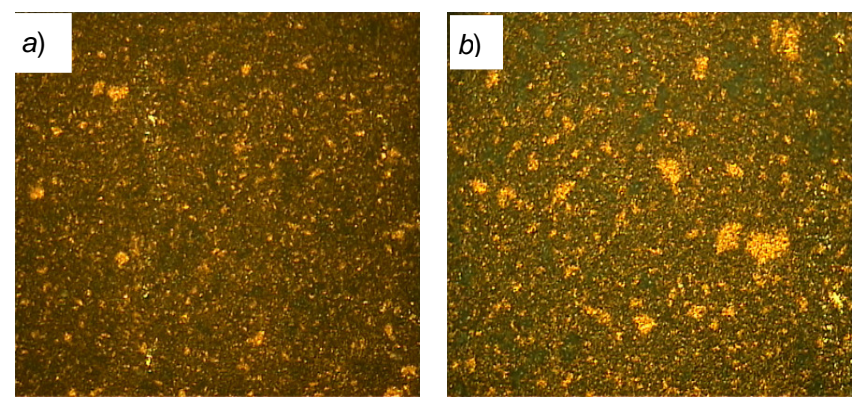

Fig. 2. Surface of $\mathrm{Cu}-\mathrm{C}_{\mathrm{D}}$ synt. $(3 \div 6 \mu \mathrm{m})$ with magnification: a) $10 \times$, b) $20 x$

Graphene composites structures were also investigated with TEM TECNAI G2 F20. Fig. 3 shows microstructure and analysis of particles composition in graphene composite $\mathrm{Cu}$ $\mathrm{C}_{\mathrm{GN}}(4)$. As it is shown in Fig. 3, the area 1 is rich in graphene, while area 2 in copper. As it is shown in Fig. 4 copper is present in a form of the large particles, mono- and polycrystalline, as well as small particles, polycrystalline. Graphene is situated around copper particles (Fig. 4).

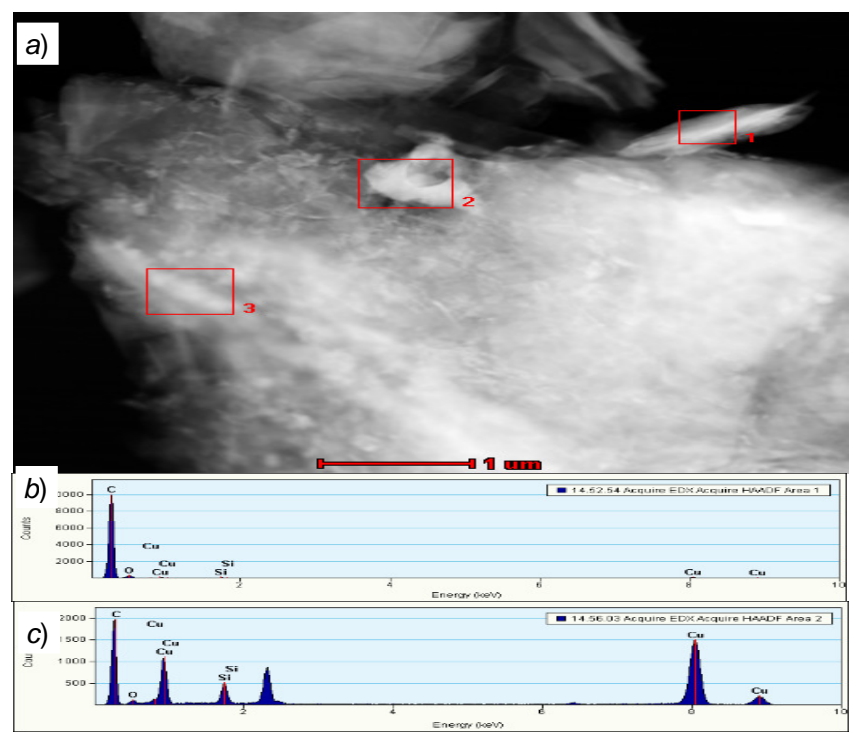

Fig. 3. TEM image a) and EDX analysis in areas b) 1 and c) 2

The density of the samples (Tab. III). was determined with the Archimedes method [2, 3]. As is visible from Tab. III, the addition of the graphene of the smaller grade resulted in slightly increased density of the composite $\mathrm{Cu}-\mathrm{C}_{\mathrm{GN}}(4)$ in comparison with the $\mathrm{Cu}-\mathrm{C}_{\mathrm{GN}}(10-20)$, opposite to density of the diamond samples $\mathrm{Cu}-\mathrm{C}_{D}(0-1)$ and $\mathrm{CU}_{\mathrm{C}} \mathrm{C}_{\mathrm{D}}(3-6)$ revealing higher density for the larger diamond particles (Tab. III).
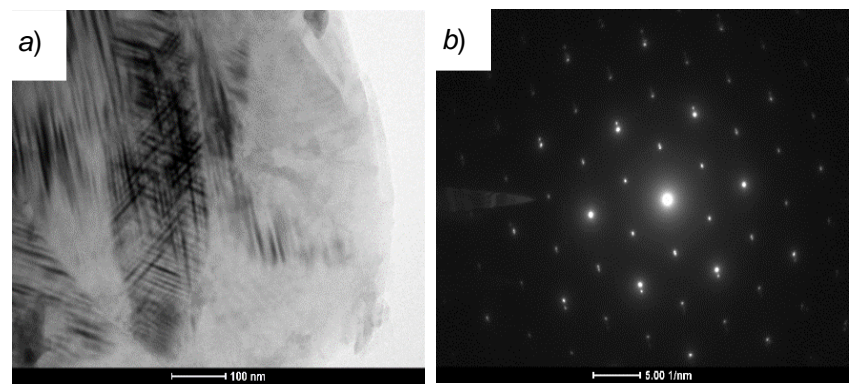

Fig. 4. TEM image of $a$ ) the Cu particle in $\mathrm{BF}, b$ ) diffraction from the Cu particle and graphene revealing [111 $]_{\mathrm{Cu}}$ and [001 $]_{\mathrm{GR}}$ orientations

Elastic properties were investigated using ultrasonic flaw detector Panametrics Epoch III. In this case elastic modulus of the dense samples is investigated basing on velocity of ultrasonic waves transition through the sample [2,3]. Results are also presented in Tab. III.

\section{TABLE III. Elastic properties}

\begin{tabular}{|l|c|c|c|c|}
\hline \multicolumn{1}{|c|}{ Sample } & $\begin{array}{c}\text { Density, } \\
\mathrm{g} / \mathrm{cm}^{3}\end{array}$ & $\begin{array}{c}\text { Density } \\
\text { error }\end{array}$ & $\begin{array}{c}\text { Poisson } \\
\text { ratio }\end{array}$ & $\begin{array}{c}\text { Elastic } \\
\text { modulus, GPa }\end{array}$ \\
\hline $\mathrm{Cu}-\mathrm{C}_{\mathrm{Gn}}(4)$ & 3.43 & 0.012 & - & - \\
\hline $\mathrm{Cu}-\mathrm{C}_{\mathrm{Gn}}(10-20)$ & 3.27 & 0.012 & - & - \\
\hline $\mathrm{Cu}-\mathrm{C}_{\mathrm{D}}(3-6)$ & 4.35 & 0.019 & 0.16 & 215 \\
\hline $\mathrm{Cu}-\mathrm{C}_{\mathrm{D}}(0-1)$ & 4.25 & 0.018 & 0.14 & 267 \\
\hline
\end{tabular}

Because of fragility of the samples containing graphene it was not possible to determine elastic properties of this samples. Compacts containing diamond revealed reduction of elastic modulus along with increasing particles sizes. For the $\mathrm{Cu}_{-} \mathrm{C}_{\mathrm{D}}(0-1)$ composite, in which diamond particle sizes were between $0 \div 1 \mu \mathrm{m}$, elastic modulus $267 \mathrm{GPa}$ was determined, while for the $\mathrm{Cu}-\mathrm{C}_{\mathrm{D}}(3-6)$ composite with diamond particles dimensions of $3 \div 6 \mu \mathrm{m}$ elastic modulus was much lower, $215 \mathrm{GPa}$. Poisson ratio for the diamond containing composites reveals opposite tendency, value of Poisson ratio increases with increasing diamond powder dimensions.

\section{Conclusions}

The grade of the graphene and diamond powders influences composites density in the opposite direction.

In Cu-GN composites the mono or polycrystalline Cu particles preserved separated character.

The $\mathrm{Cu}-\mathrm{C}_{\mathrm{D}}$ composite with the finer diamond powder revealed increased $\mathrm{E}$ modulus and decreased Poisson ratio.

\section{LITERATURE}

1. Rongrong J. "Copper-graphene bulk composites with homogeneous graphene dispersion and enhanced mechanical properties". Materials Science and Engineering: A. Vol. 654 (2016): pp. $124 \div 130$.

2. Laopaiboon R. „Elastic properties investigation of gammaradiated barium lead borosilicate glass using ultrasonic technique". Annals of Nuclear Energy. Vol. 38, No. 11 (2011): pp. $2333 \div 2337$.

3. Gaafar M.S. „Elastic properties and structural studies on some zinc-borate glasses derived from ultrasonic, FT-IR and X-ray techniques". Journal of Alloys and Compounds. Vol. 475, No. $1-2$ (2009): pp. $535 \div 542$.

4. Peng T. „Uniformly dispersion of carbon nanotube in aluminum powders by wet shake-mixing approach". Powder Technology. Vol. 284 (2015): pp.32 $\div 39$.

5. Narayan R.J. „Medical applications of diamond particles \& surfaces". Materials today. Vol. 14, No. 4 (2011): pp. 154-163. 